\begin{tabular}{|c|c|c|c|c|c|c|}
\hline (5) & $\begin{array}{l}\text { Frog alert } \\
\text { Initiative will } \\
\text { investigate decline } \\
\text { in amphibians } \\
\text { p495 }\end{array}$ & 45 & $\begin{array}{l}\text { Opening port } \\
\text { Brest to be home } \\
\text { for French } \\
\text { research fleet } \\
\text { p498 }\end{array}$ & $\begin{array}{l}\text { Clean sweep } \\
\text { Dredger captures } \\
\text { chimney from } \\
\text { marine volcano } \\
\text { p499 }\end{array}$ & 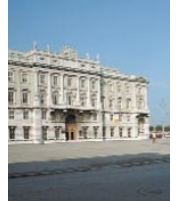 & $\begin{array}{l}\text { A moving tale } \\
\text { Science academies } \\
\text { to set up office in } \\
\text { Trieste } \\
\text { p501 }\end{array}$ \\
\hline
\end{tabular}

\title{
Researchers take US government to court over threat to turtles...
}

\section{Natasha Loder}

US marine biologists have drawn a line in the sand. In the face of rapidly dwindling numbers of Pacific leatherback turtles, they have decided that "enough is enough" and are suing the US government for failing to protect the species.

Leatherbacks are endangered throughout the world. But the numbers of the genetically distinct Pacific leatherback turtle are declining precipitously, probably because of their accidental capture by longline fishing. They become entangled in lines or hooks, and some either drown or get picked off by sharks, while many of those released by fisherman later die as a result of their capture.

Although the National Marine Fisheries Service (NMFS), the US government agency responsible for conserving and managing marine resources, recognizes Hawaiian longline fishing as the main threat to the recovery of the leatherbacks under their control, it is now permitting more accidental captures.

Last year, the service authorized an unprecedented take of 244 leatherback turtles, based on a claimed population figure of 85,000 leatherbacks. Critics dispute this population total, as well as the assumption that only a handful of those caught will die. Scientists from the Center for Marine Conservation (CMC) in Washington are now accusing the NMFS of failing to perform its mandatory duties under the US Endangered Species Act.

Pamela Plotkin, a senior conservation scientist at the CMC and the lead scientist in the legal action, says her unit had been in dispute with the NMFS over this issue for several years when it was approached by the Earth Justice Legal Defense Fund, based in Honolulu.

The non-profit law firm works in the area of environmental justice and was looking for plaintiffs to challenge the many unmanaged Hawaiian fisheries. Plotkin agrees that the action is unusual for a group of scientists, but adds: "as you work on different organisms you become passionate and committed and feel it is part of your job to speak out."

Plotkin has already testified that government figures are incorrect, and several prominent scientists have written to the judge warning him that the number of nest-

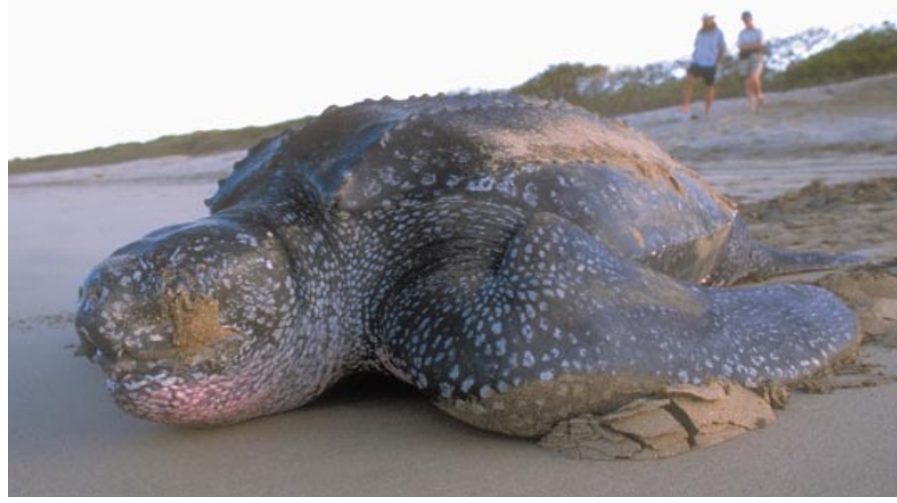

No place to hide: accidental captures in longline fishing have been a major factor in driving the leatherback turtle close to extinction.

ing turtles could be as low as 3,700, and that they are in imminent danger of extinction.

In October last year, the judge ruled that the NMFS had violated the National Environmental Policy Act by allowing a Hawaii-based longline fishery to operate without first completing an environmental impact study. He then closed thousands of square miles of the Pacific Ocean to longline fishing until the study had been completed.

Scientists from Drexel University in Philadelphia and the CMC have now produced a paper (see pages 529-30) concluding that the leatherback is on the verge of extinction in the Pacific. Their study population in
Costa Rica has fallen from 1,367 nesting females to 117 in ten years. Estimates of annual mortality for this and an important Mexican population are 35 and 20 per cent.

Jim Lecky, the assistant regional administrator for protected resources at the NMFS, says they expect to learn a lot from the lawsuit, but warns: "This is a huge international problem and we could shut down Hawaiian longline fishing tomorrow, and it would not make a dent in this." Lecky also argues that it would be unfair to put Hawaiian fishermen out of business while other countries would be able to continue fishing. A final decision is due in the next few months.

\section{...as amphibians come under study}

\section{Rex Dalton, San Diego}

A disturbing trend of population declines and birth deformities in amphibians has prompted a US federal agency to launch an ambitious research programme.

The national Amphibian Research and Monitoring Initiative (ARMI) has been set up by the US Department of the Interior with $\$ \mathbf{5}$ million to study why frogs, salamanders and toads are in such trouble. An additional \$2 million is being sought for next year's budget.

Initially, ARMI will examine amphibians on the nation's extensive federal lands, but officials hope to expand the programme to other habitats. Coordinated by the US Geological Survey (USGS), the scheme was created after scientists captured the attention of Interior Secretary Bruce Babbitt with reports of amphibian distress.

"This is now a front-burner issue," says James Hanken, herpetology curator at Harvard University's Museum of Comparative Zoology. "This is not just a plan; things are happening."

Hanken was among a group of scientists who met early last month in West Virginia to design ARMI. Officials from various federal agencies, including the National Science Foundation, the National Institutes 


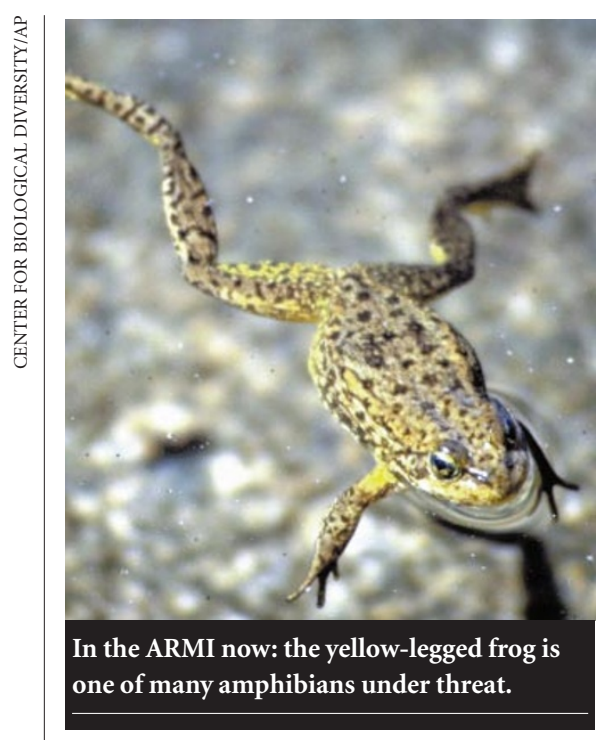

- of Health and the Environmental Protection Agency, also took part.

Under ARMI, the nation has been divided into seven regions of particular amphibian characteristics, says Daniel James, a USGS wildlife biologist who is coordinating the programme. Government agencies had strong herpetological staff in four regions, but not in the Mississippi River Valley or the Northeast, so the department is seeking new scientists to augment its resources.

Initially, researchers will survey many sites in large sections of National Parks, National Wildlife Refuges and Bureau of Land Management areas. They will then focus on a few species at a limited number of locations in an attempt to determine what ecological factors are contributing to the declines and deformities.

The ARMI effort is taking place at a time when scientists around the world are seeking better understanding of the broad declines taking place in global amphibian populations. Pollutants, increased amphibian susceptibility to disease, and decreases in the ozone layer are all being considered.

An international group of scientists, the Declining Amphibian Populations Task Force, has played a major role in spurring amphibian research. ARMI is to become the permanent home of an amphibian atlas that is now being developed, officials said.

In addition, federal officials have hired an amphibian pathologist at the National Wildlife Health Center in Madison, Wisconsin, to focus on the role of disease. ARMI also complements an on-going three-year amphibian study by the NSF, which is already providing $\$ 3$ million to 13 universities to study the causes of species declines.

\section{Green light for plans to sell off US helium reserve}

\section{Colin Macilwain, Washington}

The US government's plans to privatize the nation's helium reserve have been backed by a panel at the National Research Council (NRC). Some physicists had attacked the proposals because of the limited supply of this inert gas. But the NRC panel found that privatizing the reserve would not harm longterm supplies to researchers and other users.

The national reserve holds 30 billion cubic feet of helium - enough for ten years at current usage rates. The gas is extracted from natural gas supplies in the United States, and the physicists were worried that there would be no other source when these supplies are exhausted. Helium is used mainly for industrial cleaning and welding, and for cryogenic research.

A statement issued in 1995 by the American Physical Society (APS) expressed "profound concern" about the sale of the reserve, noting that the supply of helium has "severe natural limits". Despite this, legislation was passed in 1996 to sell off the reserve, subject to a report from the NRC and subsequent consultations with helium users.

The panel's report dismissed the physicists' concerns. The panel found that "the Helium Privatization Act of 1996 will not have a substantial impact on helium users". This clears the way for the sale of the reserve.

APS officials endorsed the composition of the NRC panel, which was chaired by Ray Beebe, a consultant engineer, and John Reppy, a physicist at Cornell University, and are expected to accept its findings.

According to Beebe, the panel looked at other materials whose sole source is as a byproduct of another commodity - including several rare metals that are only extracted as offshoots of copper mining - and concluded that such supply restrictions were unlikely to lead to a helium shortage.

The panel also found that most of the current demand for helium was being met by sources independent of the national reserve. To safeguard long-term supplies of the gas, the NRC panel recommends more research into natural gas fields with high helium content, and on helium conservation and recycling.

Asked if physicists were wrong to say that the privatization would endanger their helium supplies, Beebe said: "People who are focused on their own work will naturally be very protective of it."

http://books.nap.edu/catalog/9860.html

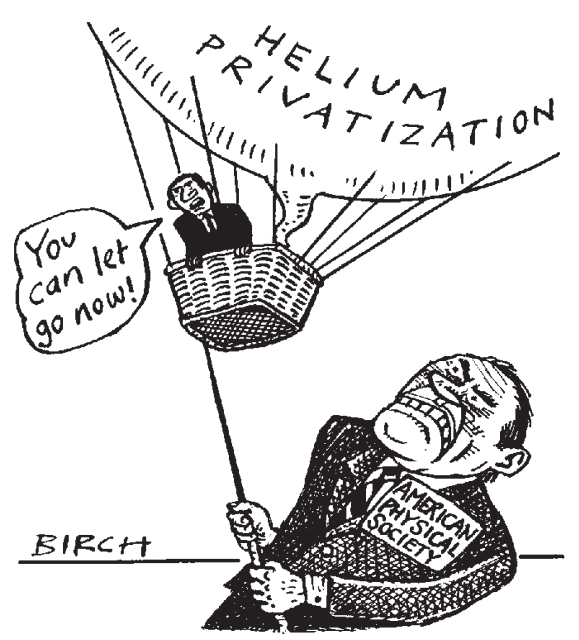

\section{UK labs impeded by old equipment}

\section{Natasha Loder, London}

More than half of the university laboratories in the United Kingdom are using outdated equipment, according to a report from Manchester University's Policy Research in Engineering, Science and Technology Institute. It says that at least $\mathfrak{E} 600$ million (US\$885 million) is needed to bring essential research facilities up to date.

The study looked at four research-intensive universities and analysed applications for recent bids to a special $£ 750$ million research infrastructure fund. It found that that two-thirds of departments had critical experiments they were unable to perform because of a lack of equipment.

Several department heads said their research strategies were driven by existing or prospective non-availability of equipment. The study also found that the fund, intended to remedy a two-decade hole in underfunding of research infrastructure, was hugely oversubscribed, falling far short of what is needed and leaving many applications rated 'excellent' unfunded.

The work was commissioned by the Committee of Vice Chancellors and Principals (CVCP), which represents the heads of UK universities. It was intended to focus minds at the Treasury, which is reviewing all areas of government spending before allocating funding for the next three years. Diana Warwick, the CVCP chief executive, describes the findings as "important", and emphasizes the "urgent need to address basic funding priorities for UK universities". 